\title{
Efficacy of fluralaner against canine generalized demodicosis
}

\section{Eficácia do fluralaner contra demodiciose canina generalizada}

\author{
Natália Lôres Lopes ${ }^{1 *}$ (D) Flávia Clare Goulart de Carvalho² (D), Renata Berman ${ }^{3}$ (D) , Marília Alves Machado ${ }^{4}$ (D), \\ Carolina de Moraes Barbalho Trivisol Medeiros ${ }^{5}$ (1) \& Julio Israel Fernandes ${ }^{6}$ (i) \\ 'Médica veterinária, MSc, Programa de Pós-graduação em Medicina Veterinária , Universidade Federal Rural do Rio de Janeiro \\ - UFRRJ, Seropédica, RJ, Brasil \\ 2Médica veterinária, PhD. Professora na UNIFAA e UNIG, RJ,Brasil \\ ${ }^{3}$ Médica veterinária autônoma. Teresópolis, Rio de Janeiro, Brasil \\ ${ }^{4}$ Médica veterinária. Programa de Pós-graduação em Ciências Veterinárias, Universidade Federal Rural do Rio de Janeiro - \\ UFRRJ, Seropédica, RJ, Brasil \\ ${ }^{5}$ Médica Veterinária. Programa de Residência em Medicina Veterinária, Universidade Federal Rural do Rio de Janeiro - UFRRJ, \\ Seropédica, RJ, Brasil \\ ${ }^{6}$ Médico Veterinário, PhD. Departamento de Medicina e Cirurgia Veterinária, Universidade Federal Rural do Rio de Janeiro - \\ UFRRJ, Seropédica, RJ, Brasil
}

\begin{abstract}
Demodicosis is a parasitic dermatopathy, resulting from the excessive proliferation of Demodex mites. The rate at which this disease is encountered in the pet clinic is high, despite recent advances in the treatment of the disease. The aim of this study, which was conducted in Brazil, was to analyze the efficacy of fluralaner in the treatment of demodicosis in dogs. Fifteen dogs with generalized demodicosis that were diagnosed with Demodex sp. mites from skin scraping were included. All animals were treated with fluralaner at a dose of $25 \mathrm{mg} / \mathrm{kg}$, following the manufacturer's recommendations for the treatment of ectoparasites. The effectiveness of the treatment was evaluated based on clinical improvement of the animals and the time required to obtain two consecutive negative skin scrapes 30 days apart (parasitological cure). The main clinical signs observed were alopecia (100\%; 15/15); erythema (86.7\%; 10/15); and hypotrichosis, papule, crusts, hyperpigmentation, and hyperkeratosis (26.7\%; 4/15). Of the 15 animals evaluated, two of them were excluded for not returning for the second evaluation in 60 days, although they had the first negative skin scrape. After 30 days, six (46.2\%) from 13 animals that concluded the study presented the first negative skin scraping. At the end of the study, all dogs presented parasitological cure and clinical improvement, except for three animals. One for developing atopic dermatitis and two that lived in an animal shelter. In conclusion, a single oral dose of fluralaner is effective in the treatment of generalized demodicosis in dogs.
\end{abstract}

Keywords: dogs, acaricidal, isoxazolines.

\section{Resumo}

Demodiciose é uma dermatopatia parasitária, decorrente da proliferação excessiva de ácaros do gênero Demodex. A doença apresenta alta ocorrência na clínica de animais de companhia, apesar dos recentes avanços no tratamento da doença. O objetivo deste estudo controlado, realizado no Brasil, foi reportar a eficácia do fluralaner, no tratamento da demodiciose em cães. Foram incluídos 15 cães apresentando demodiciose generalizada, diagnosticados com ácaros do gênero Demodex, a partir do raspado cutâneo. Todos os animais foram tratados com fluralaner na dose de $25 \mathrm{mg} / \mathrm{kg}$, seguindo as recomendações do fabricante para o tratamento de ectoparasitos. A eficácia do tratamento foi avaliada pela melhora clínica dos animais e o tempo necessário para a obtenção de dois raspados negativos consecutivos com intervalo de 30 dias (cura parasitológica). Os principais sinais clínicos observados foram alopecia (100\%; 15/15); eritema (86,7\%; 10/15); e hipotricose, pápulas, crostas, hiperpigmentação e hiperqueratose $(26,7 \%$; 4/15). Dos 15 animais avaliados, dois deles foram excluídos do estudo por não retornarem para a segunda avalaição em 60 dias, embora tivessesm apresentado um raspado negativo. Após 30 dias, dos 13 animais que concluíram o estudo, (46,2\%; 6/13) apresentaram o primeiro raspado negativo. Ao final do período experimental, todos os animais apresentaram cura parasitológica e melhora clínica, exceto em três animais, um por apresentar atopia posteriormente e outros dois casos, cujo animais eram oriundos de abrigo. Conclui-se que que uma única dose oral do fluralaner é efetiva no tratamento da demodiciose generalizada em cães.

Palavras-chave: cães, acaricida, isoxazolina.
How to cite: Lopes, N. L., Carvalho, F. C. G., Berman, R., Machado, M. A., Trivisol-Medeiros, C. M. B. \& Fernandes, J. I. (2019). Efficacy of fluralaner against canine generalized demodicosisx. Brazilian Journal of Veterinary Medicine, 41, e101719. doi: https://doi.org/10.29374/2527-2179.bjvm101719

Financial support: This study was financed in part by the Coordenação de Aperfeiçoamento de Pessoal de Nível Superior - Brasil (CAPES) Finance Code 001.

Conflict of interests: No conflict of interests declared concerning the publication of this article.

Received: December 12, 2018.

Accepted: June 16, 2019.

The study was carried out at the Serviço de Dermatologia, Universidade Federal Rural do Rio de Janeiro, Serviço de Dermatologia da Clínica da Universidade Severino Sombra e dois abrigos para cães no Brasil.

\section{*Correspondence}

Natália Lôres Lopes

Universidade Federal Rural do Rio de Janeiro - UFRRJ

Campus Seropédica

CEP 23851-790 - Seropedica (RJ), Brasil.

E-mail: natloesvet@gmail.com 


\section{Introduction}

Demodicosis is considered the most prevalent parasitic skin disease (Delayte, 2016) and is characterized by the presence of larger than normal numbers of demodectic mites diagnosed by deep skin scrapings (Miller et al., 2013).

Treatment of this dermatopathy is multimodal and includes acaricidal therapy, treatment of concurrent bacterial skin infection, internal parasitism and identification of underlying systemic disease (Mueller et al., 2012). The therapeutic end-point is determined by multiple negative skin scrapings, in addition to resolution of clinical signs (Mueller et al., 2012).

Over the years, treatment with topical amitraz (Ghubash, 2006; Kosh et al., 2012) and macrocyclic lactones such as avermectins and milbemycins (Sartor \& Santarem, 2006; Singh et al., 2011) have been used as acaricidal therapy. However, the possibility of developing adverse effects, due to its administration, has been described (Sartor e Santarem, 2006; Delayte et al., 2006; Singh et al., 2011). Additionally, macrocyclic lactones are not indicated for use in dogs with a mutation of ABCB1-1 (MDR-1) gene (Ghubash, 2006; Kosh et al., 2012).

Recently, it was discovered that oral administration of isoxazolines, a class of drugs that act as potent blockers of the GABA gated chloride channel (Lahm et al., 2013), has a remarkable effect on fleas and ticks (Mctier et al., 2016). Fluralaner belongs to this new class and has prolonged activity against fleas and ticks after a single oral dose (Kilp et al., 2014) of $25 \mathrm{mg} / \mathrm{kg}$, with no adverse effects observed during a safety trial, even at higher doses (Walther et al., 2014). No side effects were observed by the authors of previous studies either (Taenzler et al., 2014; Wengenmayer et al., 2014; Fourie et al., 2015). However, one study reported inappetence, vomiting, and diarrhea (Rohdich et al., 2014). The bioavailability of fluralaner was increased when administered with food (Walther et al., 2014).

This compound was successfully used in parasitic skin diseases as miticidal therapy for sarcoptic mange (Romero et al., 2016) and demodicosis (Fourie et al., 2015; Duangkaew et al., 2018). Against generalized demodicosis, its administration resulted in 99.8\% reduction of the mean mite observed by skin scrapings 28 days after treatment, while a $100 \%$ reduction was observed in 56 days after treatment (Fourie et al., 2015). In comparison, treatment withivermectin can take up to 90 days to obtain the first negative skin scraping (Delayte et al., 2006). Arias \& Cordero (2016) reported fluralaner efficacy with its administration at 2-month intervals to treat this skin disease. Recently, in Brazil, there is a report on the efficacy in two generalized demodicosis cases treated with fluralaner (Bezerra et al., 2017).

As fluralaner is a new medication, there are only few publications that employ different treatment protocols. However, the aim of the current study was to assess the efficacy of oral fluralaner administration against 15 cases of generalized demodicosis.

\section{Material and methods}

The present study was a multicenter retrospective study involving two clinics (The Dermatology Service at the Universidade Federal Rural do Rio de Janeiro Veterinary Hospital and the Dermatology Service at the Universidade Severino Sombra Veterinary Clinic) and two dog shelters in Brazil. This study was submitted and approved by the Veterinary institute Ethics Committee (CEUA-4851170317 and CEUA 040/2018).

Fifteen dogs diagnosed with demodicosis by deep skin scrapings that were positive for Demodex mites (immature or adult) were included in the present study. Five dogs were from a dog shelter. All of them presented with the clinical signs of generalized demodicosis, showing lesions such as alopecia, hypotrichosis, erythema, comedones, scale, and crusts involving an entire body region, pododemodicosis, or at least five localized lesions. Breed, sex, and age were recorded. Dogs that were receiving immunosuppressive drugs or those treated with acaricidal therapy within 60 days were not included.

Fluralaner was orally administered with food, at a dose of $25 \mathrm{mg} / \mathrm{kg}$, following the manufacturer's recommendation. Fourteen dogs were bathed with benzoyl peroxide $2.5 \%$ shampoo and one dog was bathed with chlorhexidine 3\% shampoo every 7 days. Dogs with superficial or deep pyoderma received systemic antimicrobial therapy. 
Deep skin scrapings were performed in all dogs on day 0 and every 30 days, until the occurrence of two consecutive negative scrapings. Parasitological cure was considered if two deep skin scrapings were negative at 1-month interval. Samples were collected from five lesion areas, approximately $1 \mathrm{~cm}^{2}$ each, using a scalpel blade. The skin was squeezed during the scrapping and examined using a microscope under 40x or 100x magnification to observe immature or adult Demodex mites, in order to classify as positive or negative. The clinical signs and dermatological lesions were evaluated and recorded on day $\mathrm{O}$ and on the same day of skin scrapings.

For statistical analysis, Fischer`s exact test was used to compare deep skin scrapings (negative or positive) before and after treatment and the presence of skin lesions before and after treatments, with $P$ values $\leq 0.05$ were considered significant.

\section{Results}

Fifteen dogs were included in the present study. Data on animals, such as sex, age, classification of lesions, and follow-up of animals after treatment are described in Table1. The age ranged from 6 months to 7 years, with 14 (93.33\%) dogs aging up to 1 year old and only one (6.66\%) being 7 years old. Seven were female (47\%) and 8 were male (53\%).

Breeds included were American Bully (2), beagle (1), Teckel (1), Frenchie bulldog (1), Pinscher (1), Pit bull (2), Pug (1), Shih-tzu (1) and mixed breed dog (5). Dogs living in a dog shelter corresponded to 33\% (5/15), while 67\% (10/15) were household. The most frequent skin lesion observed were alopecia 100\% (15/15), followed by erythema 86.7\% (13/15) and hypotrichosis, papule, crusts, hyperpigmentation, and hyperkeratosis $26.7 \%$ (4/15). Other lesions observed were scale and pustule (20\%; 3/15) and comedo, ulcer, and collarette (6.7\%; 1/15). Two dogs that already had negative skin scrapings as of 30 days after medication were lost to follow-up; thus, they were excluded from the study.

All patients (100\%) showed negative skin scrapings after the treatment, with 46.15\% (6/13) obtaining their first negative skin scraping after 30 days, and second scraping on day +60 , as described in Table 1. On day 30, it was observed that two dogs had full recovery of skin lesions (13.33\%). All dogs showed clinical improvement on day 30, and 69.23\% (9/13) showed clinical cure.

Table 1. Clinical presentation of dogs diagnosed with demodicosis evaluated until parasitical cure.

\begin{tabular}{|c|c|c|c|c|c|c|c|}
\hline \multirow{2}{*}{ Animal } & \multirow{2}{*}{ Breed } & \multirow{2}{*}{ Age } & \multirow{2}{*}{ Sex } & \multirow{2}{*}{ Clinical finding } & \multicolumn{3}{|c|}{ Scrap days } \\
\hline & & & & & Day +30 & Day +60 & Day +90 \\
\hline 1 & SRD & 3y & $\mathrm{M}$ & Alopecia, ulcer, crusts & - & $\therefore$ & - \\
\hline 2 & $\mathrm{SRD}$ & 3y & M & Alopecia, erythema, hyperkeratosis & - & $-*$ & - \\
\hline 3 & SRD & $1 y$ & M & Erythema, papules, pustule, alopecia & - & $-*$ & - \\
\hline 4 & SRD & $1 y$ & F & Descamation, erythema, alopecia, hyperkeratosis & + & - & $-*$ \\
\hline 5 & Beagle & $7 y$ & M & Alopecia, erythema, hyperpigmentation & - & $-*$ & - \\
\hline 6 & SRD & $1 y$ & $\mathrm{~F}$ & Descamação, erythema, alopecia, hyperkeratosis & + & - & $-*$ \\
\hline $7^{*}$ & Teckel & $6 \mathrm{~m}$ & M & Papule, hypotrichosis, erythema, alopecia & - & Exc & Exc \\
\hline 8 & Frenchie bulldog & $8 \mathrm{~m}$ & M & Pustule, papule, erythema, alopecia & - & $-*$ & - \\
\hline 9 & Pinscher & $2 y$ & M & $\begin{array}{l}\text { Hypotrichosis, alopecia, pustule, erythema, } \\
\text { hyperpigmentation, hyperkeratosis }\end{array}$ & + & - & $-*$ \\
\hline $10^{*}$ & Pit bull & $7 \mathrm{~m}$ & F & Alopecia, erythema, hypotrichosis, comedos & - & Exc & Exc \\
\hline 11 & Pit bull & $6 \mathrm{~m}$ & F & Alopecia, erythema, Crusts & + & - & $-*$ \\
\hline 12 & Pug & $7 \mathrm{~m}$ & F & pustule, alopecia, erythema & + & - & $-*$ \\
\hline 13 & Shih tzu & $7 y$ & M & Alopecia, crusts, hyperpigmentation, descamation & + & - & $-*$ \\
\hline 14 & American bully & $6 \mathrm{~m}$ & F & papules, pustule, alopecia, erythema, hypotrichosis & + & - & $-*$ \\
\hline 15 & American bully & $4 \mathrm{~m}$ & $\mathrm{~F}$ & crusts, descamation, erythema, alopecia & - & $-*$ & - \\
\hline
\end{tabular}

Age: (m) months; (y) years; Sex: (M) male; (F) female; (Exc) animal excluded; ${ }^{*}$ ) Parasitological cure. 
For 53.8\% (7/13) of the animals, the first negative scraping was observed in the second clinical examination, on day +60 . These animals had a second negative scrape on day +90 , including the six animals that had already showed two consecutives negative scrapes on day +60 . All animals followed up until the end showed parasitological cure on day +90 , a date that is recommended by manufacturer for another drug administration. For 23.1\% (3/13), even after presenting their third negative skin scraping after 90 days still presented with skin lesions. However, one was later diagnosed with atopic dermatitis and the other two showed some significant improvement. No adverse effects were observed throughout the treatment.

\section{Discussion}

Generalized demodicosis usually starts in dogs aged 3 to 18 months (Miller et al., 2013), as in this study, with most of the dogs aging up to 1 year old. As observed in this study, erythema, alopecia, papules, and crusts are described as clinical signs of canine demodicosis (Mueller et al., 2012; Miller et al., 2013).

The efficacy of the treatment of demodicosis with isoxazolines has been described (Six et al., 2016; Snyder et al., 2017; Lebon et al., 2018). The oral treatment of this disease with fluralaner was effective as observed by other authors (Fourie et al., 2015; Bezerra et al., 2017; Duangkaew et al., 2018) with a single-dose administration. All the dogs obtained negative deep skin scrapings.

In most of the dogs (60\%) after 30 days of treatment, it was not observed no Demodex mite and after 60 days, all the patients had negative skin scrapings. Bezerra et al. (2017) reported negative deep skin scraping after 75 days, although it was not tested after 30 days of In one study, reduction in mean mite number was observed in $99.8 \%$ of treatmente. cas s after 28 days of treatment and in 100\% after 56 days of treatment (Fourie et al., 2015); this finding is in line with the observation that on day 60 , there was no positive deep skin scraping. One limitation of this study was the lack of mean mite numbers obtained in each evaluation. Ivermectin is one of the drugs commonly used to treat this disease and it was observed that the first skin scraping took 90 days to turn negative (Delayte et al., 2006), unlike the results observed with fluralaner.

The good clinical response in most of the patients also corroborates the efficacy of the treatment, which has been reported by other authors as well (Fourie et al., 2015; Bezerra et al., 2017). The fact that one of the dogs did not show a full recovery may be explained by the diagnosis of atopic dermatitis at a later stage, which had erythema and alopecia among the skin lesions commonly observed (Salzo, 2016). The two other cases were from a dog shelter, which favors stress situation and may explain the delay in improvement.

As observed by other authors (Taenzler et al., 2014; Wengenmayer et al., 2014; Fourie et al. 2015), no side effects were observed in the current study. The drugs normally used to treat generalized demodicosis may have some side effects (Sartor e Santarem, 2006; Singh et al., 2011, Delayte et al., 2006); however, fluralaner treatment was both effective and safe.

\section{Conclusion}

In conclusion, a single oral dose of fluralaner may be effective in treating canine generalized demodicosis.

\section{References}

Arias, P. T., \& Cordero, A. M. (2016). Effectiveness of fluralaner (Bravecto_MSD) in treating generalized demodicosis in four dogs. Veterinary Dermatology, 27, 6-12.

Bezerra, J. A. B., Cardoso, I. R. S., Rodrigues, R. T. G. A., \& Filgueira, K. D (2017). Uso do fluralaner no tratamento da demodiciose canina juvenil generalizada: Relato de caso. Arquivo Brasileiro de Medicina Veterinária e Zootecnia, 69(6), 1491-1495. http://dx.doi.org/10.1590/1678-4162-9586.

Delayte, E. H., Otsuka, M., Larsson, C. E., \& Castro, R. C. C. (2006). Eficácia das lactonas macrocíclicas sistêmicas (ivermectina e moxidectina) na terapia da demodicidose canina generalizada. Arquivo Brasileiro de Medicina Veterinária e Zootecnia, 58(1), 31-38. http://dx.doi.org/10.1590/S0102-09352006000100006.

Delayte, E. H. (2016). Demodiciose canina. In C. E. Larsson \& R. Lucas. Tratado de medicina externa-dermatologia veterinária (1a ed., pp. 369-389). São Caetano do Sul: Interbook. 
Duangkaew, L., Larsuprom, L., Anukkul, P., Lekcharoensuk, C., \& Chen, C. (2018). A field trial in Thailand of the efficacy of oral fluralaner for the treatment of dogs with generalized demodicosis. Veterinary Dermatology, 29(3), 1-6. http://dx.doi.org/10.1111/vde.12524. PMid:29424108.

Fourie, J. J., Liebenberg, J. E., Horak, I. G., Taenzler, J., Heckeroth, A. R., \& Frénais, R. (2015). Efficacy of orally administered fluralaner (Bravecto ${ }^{\mathrm{TM}}$ ) or topically applied imidacloprid/moxidectin (Advocate ${ }^{\circledast}$ ) against generalized demodicosis in dogs. Parasites \& Vectors, 8(187), 1-7. PMid:25881320.

Ghubash, R. (2006). Parasitic miticidal therapy. Clinical Techniques in Small Animal Practice, 21(3), 135-144. http:/l dx.doi.org/10.1053/j.ctsap.2006.05.006. PMid:16933480.

Kilp, S., Ramirez, D., Allan, M. J., Roepke, R. K., \& Nuernberger, M. C. (2014). Pharmacokinetics of fluralaner in dogs following a single oral or intravenous administration. Parasites \& Vectors, 7(85), 1-5. http://dx.doi. org/10.1186/1756-3305-7-85. PMid:24606874.

Kosh, S. N., Torres, S. M. F., \& Plumb, D. C. (2012). Canine and feline dermatology drug handbook (1st ed.). Iowa: Wiley-Blackwell.

Lahm, G. P., Cordova, D., Barry, J. D., Pahutski, T. F., Smith, B. K., Long, J. K., Benner, E. A., Holyoke, C. W., Joraski, K., Xu, M., Schroeder, M. E., Wagerle, T., Mahaffey, M. J., Smith, R. M., \& Tong, M. H. (2013). 4-Azolylphenyl isoxazoline insecticides acting at the GABA gated chloride channel. Bioorganic \& Medicinal Chemistry Letters, 23(10), 3001-3006. http://dx.doi.org/10.1016/j.bmcl.2013.03.031. PMid:23566518.

Lebon, W., Beccati, M., Bourdeau, P., Brement, T., Bruet, V., Cekiera, A., Crosaz, O., Darmon, C., Guillot, J., Mosca, M., Pin, D., Popiel, J., Pomorska Handwerker, D., Larsen, D., Tielemans, E., Beugnet, F., \& Halos, L. (2018). Efficacy of two formulations of afoxolaner (NexGard ${ }^{\circledR}$ and NexGard Spectra ${ }^{\circledR}$ ) for the treatment of generalised demodicosis in dogs, in veterinary dermatology referral centers in Europe. Parasites \& Vectors, 11(1), 1-10. http://dx.doi.org/10.1186/s13071-018-3083-2. PMid:30201031.

McTier, T. L., Chubb, N., Curtis, M. P., Hedges, L., Inskeep, G. A., Knauer, C. S., Menon, S., Mills, B., Pullins, A., Zinser, E., Woods, D. J., \& Meeus, P. (2016). Discovery of sarolaner: A novel, orally administered, broadspectrum, isoxazoline ectoparasiticide for dogs. Veterinary Parasitology, 222, 3-11. http://dx.doi.org/10.1016/j. vetpar.2016.02.019. PMid:26961590.

Miller, W. H., Griffin, C. E., \& Campbell, K. L. (2013). Muller and Kirk's small animal dermatology (7th ed.). St Louis: Elsevier.

Mueller, R. S., Bensignor, E., Ferrer, L., Holm, B., Lemarie, S., Paradis, M., \& Shipstone, M. A. (2012). Treatment of demodicosis in dogs: 2011 clinical practice guidelines. Veterinary Dermatology, 23(2), 86-96. http://dx.doi. org/10.1111/j.1365-3164.2011.01026.x. PMid:22329600.

Rohdich, N., Roepke, R. K., \& Zschiesche, E. (2014). A randomized, blinded, controlled and multi-centered field study comparing the efficacy and safety of Bravecto (fluralaner)againstFrontline (fipronil) in flea- and tickinfested dogs. Parasites \& Vectors, 7(83), 1-5. PMid:24593931.

Romero, C., Heredia, R., Pineda, J., Serrano, J. A., Mendoza, G. D., Trápala, P., \& Cordero, A. M. (2016). Efficacy of fluralaner in 17 dogs with sarcoptic mange. Veterinary Dermatology, 27(5), 353-e88. http://dx.doi.org/10.1111/ vde.12363. PMid:27511592.

Salzo, P. S. (2016). Dermatite atópica. In C. E. Larsson \& R. Lucas. Tratado de medicina externa- dermatologia veterinária (1st ed., pp. 513-529). São Caetano do Sul: Interbook.

Sartor, I. F., \& Santarem, V. A. (2006). Agentes empregados no controle de ectoparasitos. In H. S. Spinosa, S. L. Gorniak, \& M. M. Bernardi. Farmacologia aplicada à medicina veterinária (4th ed., pp. 567-583). Rio de Janeiro: Guanabara Koogan.

Singh, S. K., Kumar, M., Jadhav, R. K., \& Saxen, S. K. (2011). An update on therapeutic management of canine demodicosis. Veterinary World, 4(1), 41-44. http://dx.doi.org/10.5455/vetworld.2011.41-44.

Six, R. H., Becskei, C., Mazaleski, M. M., Fourie, J. J., Mahabir, S. P., Myers, M. R., \& Slootmans, N. (2016). Efficacy of sarolaner, a novel oral isoxazoline, against two common mite infestations in dogs: Demodex spp. and Otodectes cynotis. Veterinary Parasitology, 222, 62-66. http://dx.doi.org/10.1016/j.vetpar.2016.02.027. PMid:26971196.

Snyder, D. E., Wiseman, S., \& Liebenberg, J. E. (2017). Efficacy of lotilaner (Credelio ${ }^{\mathrm{TM}}$ ), a novel oral isoxazoline against naturally occurring mange mite infestations in dogs caused by Demodex spp. Parasites \& Vectors, 11(1), 1-10. http://dx.doi.org/10.1186/s13071-017-2472-2. PMid:29089049.

Taenzler, J., Wengenmayer, C., Williams, H., Fourie, J., Zschiesche, E., Roepke, R. K. A., \& Heckeroth, A. R. (2014). Onset of activity of fluralaner (BRAVECTO ${ }^{\mathrm{TM}}$ ) against Ctenocephalides felis on dogs. Parasites \& Vectors, 7(567), 1-4. PMid:25471474.

Walther, F. M., Allan, M. J., Roepke, R. K., \& Nuernberger, M. C. (2014). The effect of food on the pharmacokinetics of oral fluralaner in dogs. Parasites \& Vectors, 7(84), 1-4. http://dx.doi.org/10.1186/1756-3305-7-84. PMid:24598049.

Wengenmayer, C., Williams, H., Zschiesche, E., Moritz, A., Langenstein, J., Roepke, R. K., \& Heckeroth, A. R. (2014). The speed of kill of fluralaner (Bravecto ${ }^{\mathrm{TM}}$ ) against Ixodes ricinus ticks on dogs. Parasites \& Vectors, 7(525), 1-5. PMid:25406442. 